\title{
ANALISIS PENDAPATAN RETRIBUSI DALAM MENUNJANG PENDAPATAN ASLI DAERAH (PAD) KOTA METRO
}

\author{
Oleh : \\ Diah Rosanti \\ Email: dia_rosanti@yahoo.co.id \\ Fakultas Ekonomi, Universitas Muhammadiyah Metro
}

\begin{abstract}
In the framework of the implementation of regional autonomy in accordance with the Act-Act 32 of 2004 on local government. Local governments are required to be able to organize and manage his household broadly and comprehensively based on existing regulations and develop and increase local revenue. The purpose of this study was to determine how much contribution levy of public services, business services, licensing certain to support the Local Revenue Metro City. The method used in this research is descriptive quantitative method is to do research on the object of the research that produced the data - the data information that is associated with the research that will be studied.

The contribution of each type of area to PAD revenues in the period 2010 to 2014 fiscal year very flukuatif. Contributions contained in a levy of General Services is the average-average contribution of five years by $27 \%$, the levy Business Services 4\%, Levy Licensing Certain 2\%, while $67 \%$ is the result of PAD others sourced from the Hotel Tax, Amusement Tax, Advertisement Tax, Tax Street Lighting (PLN and ULC Siwo Mego), Income Tax Minerals Group C and Tax concession Swallow nests and Seriti.
\end{abstract}

\section{Keywords: Revenue, Levy, PAD}

\section{PENDAHULUAN \\ Latar Belakang}

Pada masa sekarang ini dengan perubahan paradigma pemerintah ditandai dengan lahirnya Undang-Undang Nomor 22 tahun 1999 yang kemudian di revisi dengan Undang- Undang Nomor 32 tahun 2004 dan Undang-Undang Nomor 25 tahun 1999 yang kemudian di revisi dengan Undang-Undang Nomor 33 tahun 2004, pemerintah pusat mencoba meletakan arti penting otonomi daerah pada posisi yang sebenarnya, yaitu bahwa otonomi daerah adalah kewenangan daerah otonom untuk mengatur dan mengurus kepentingan masyarakat menurut prakarsa sendri berdasarkan aspirasi masyarakat sesuai aturan perundangan. Kewenangan daerah tersebut mencakup seluruh bidang pemerintahan, kecuali bidang 
kewenangan dalam bidang politik luar negeri, pertahanan keamanan, peradilan, moneter dan fiskal, agama serta kewenangan bidang lain.

Kota Metro sebagai daerah otonom yang turut melaksanakan otonom dituntut kemandiriannya dalam semua bidang, khususnya dalam hal pendanaan penyelengaraan pemerintah Kota Metro harus mampu berperan aktif dalam pengelolaan sumber-sumber keuangan yang dikuasainya, dan retribusi daerah sebagai salah satu pendanaan yang bukan semata untuk mencari profit tetapi juga memberikan manfaat/imbalan balik langsung kepada masyarakat.

\section{RUMUSAN MASALAH}

Bertitik tolak pada masalah seperti itu, perumusan masalah retribusi pada PAD ini adalah sebagai berikut:

1. Berapa besar pendapatan retribusi jasa umum yang bersumber dari retribusi pelayanan persampahan/kebersihan, retribusi pelayanan parkir ditepi jalan umum, retribusi pelayanan pasar dalam menunjang PAD Kota Metro?

2. Berapa besar pendapatan retribusi jasa usaha yang bersumber dari retribusi pasar grosir/pertokoan, retribusi tempat khusus parkir, retribusi penyedotan kakus dalam menunjang PAD Kota Metro?

3. Berapa besar pendapatan retribusi perizinan tertentu yang bersumber dari retribusi izin mendirikan bangunan (IMB), dan retribusi izin peruntukan penggunaan tanah (IPPT) dalam menunjang PAD Kota Metro?

\section{KAJIAN TEORITIK}

\section{Pendapatan Asli Daerah (PAD)}

Pendapatan daerah adalah semua hak daerah yang diakui sebagai penambah nilai kekayaan bersih dalam periode anggaran tertentu (UU No. 32 Tahun 2004 tentang pemerintahan daerah), pendapatan daerah berasal dari penerimaan dari dana perimbangan pusat dan daerah, juga yang berasal daerah itu sendiri yaitu pendapatan asli daerah serta lain-lain pendapatan yang sah.

\section{Retribusi Daerah}

Retribusi Daerah, adalah pungutan daerah sebagai pembayaran atas jasa atau pemberian izin tertentu yang khusus disediakan dan/atau diberikan oleh Pemerintah Daerah untuk kepentingan orang pribadi atau badan.

\section{Golongan Retribusi Daerah}

Undang-Undang Nomor 34 tahun 2003 Pasal 18 ayat 1 menentukan bahwa objek retribusi adalah berbagai jasa tertentu yang disediakan oleh pemerintah daerah. Tidak semua jasa yang disediakan oleh pemerintah daerah dapat dipungut retribusinya, hanya jasa-jasa tertentu yang merupakan pertimbangan sosial ekonomi layak dijadikan objek retribusi. 
Jasa retribusi daerah tersebut dibagi menjadi tiga golongan, yaitu:

1. Retribusi Jasa Umum, yaitu retribusi atas jasa yang disediakan oleh Pemerintah Daerah untuk tujuan kepentingan dan kemamfaatan umum serta dapat dinikmati oleh orang pribadi atau badan.

2. Retribusi Jasa Usaha, yaitu retribusi atas jasa yang disediakan oleh Pemerintah Daerah dengan menganut prinsip komersial karena pada dasarnya dapat disediakan oleh sektor swasta.

3. Retribusi Perizinan Tertentu, yaitu retribusi atas kegiatan tertentu Pemerintah Daerah dalam rangka pemberian izin kepada orang pribadi atau badan yang dimaksudkan untuk pembinaan, pengaturan, pengendalian, dan pengawasan atas kegiatan pemamfaatan ruang, penggunaan sumber daya alam, barang, sarana, prasarana, atau fasilitas tertentu guna melindungi kepentingan umum dan menjaga kelestarian lingkungan.

Jenis-jenis retribusi daerah tersebut adalah sebagai berikut:

1. Jenis-jenis Retribusi Jasa Umum:
a) Retribusi Pelayanan Kesehatan
b) Retribusi Pelayanan Persampahan/ Kebersihan
c) Retribusi Penggantian Biaya Cetak Kartu Tanda Penduduk dan Akta Catatan Sipil
d) Retribusi Pelayanan Pemakaman dan Penguburan Mayat
e) Retribusi Pelayanan Parkir di Tepi Jalan Umum
f) Retribusi Pelayanan Pasar
g) Retribusi Pengujian Kendaraan Bermotor
h) Retribusi Pemeriksaan Alat Pemadam Kebakaran
i) Retribusi Penggantian Biaya Cetak Peta
j) Retribusi Pengujian Kapal Perikanan.

2. Jenis-jenis Retribusi Jasa Usaha:
a) Retribusi Pemakaian Kekayaan Daerah;
b) Retribusi Pasar Grosir dan/atau Pertokoan
c) Retribusi Tempat Pelelangan
d) Retribusi Terminal
e) Retribusi Tempat Khusus Parkir
f) Retribusi Tempat Penginapan/Pesanggraha/Villa
g) Retribusi Penyedotan Kakus
h) Retribusi Rumah Potong Hewan
i) Retribusi Pelayanan Pelabuhan Kapal
j) Retribusi Tempat Rekreasi dan Olahraga
k) Retribusi Penyeberangan di Atas Air
1) Retribusi Pengolahan Limbah Cair
m) Retribusi Penjualan Produksi Usaha Daerah. 
3. Jenis-jenis Retribusi Perizinan Tertentu:

a) Retribusi Izin Mendirikan Bangunan

b) Retribusi Izin Tempat Penjualan Minuman Beralkohol

c) Retribusi Izin Gangguan

d) Retribusi Izin Peruntukan Penggunaan Tanah

\section{Kriteria Retribusi Daerah}

Kriteria retribusi jasa umum:

1. Termasuk dalam kelompok urusan pemerintah yang diserahkan kepda daerah dalam rangka desentralisasi.

2. Selain melayani kepentingan umum dan kemanfaatan umum juga member manfaat khusus bagi pribadi atau badan yang dikenakan retribusi.

3. Akan dianggap layak jika retribsusi tersebut hanya disediakan bagi pribadi atau badan yang membayar retribusi.

4. Tidak bertentangan dengan kebijaksanaan nasional mengenai penyelenggaraan jasa.

5. Dipungut secara efektif dan efisien serta sumber pendapatan daerah yang potensial.

6. Menguntungkan penyediaan jasa dengan kualitas pembayaran yang memadai.

Kriteria retribusi jasa usaha:

1. Bersifat komersial yang seharusnya disediakan sektor swasta tetapi belum memadai.

Contoh: sarana pasar.

2. Terdapat harta yang dimiliki daerah belum dimanfaatkan.

Kriteria retribusi perizinan tertentu:

1. Merupakan urusan pemerintahan yang diserahkan kepada daerah dalam rangka asas desentralisasi.

2. Perizinan benar digunakan untuk melindungi kepentingan umum.

3. Perizinan tidak bertentangan dengan perizinan yang diselenggarakan pemerintah yang lebih tinggi.

4. Biaya yang menjadi beban daerah dalam menyelenggarakan perizinan cukup besar, sehingga layak untuk dibiayai sebagaian atau seluruh dari retribusi perizinan.

\section{Objek Retribusi}

Menurut Mardiasimo (2003:103) objek retribusi daerah terdiri dari:

1. Jasa umum, yaitu berupa pelayanan yang disediakan atau diberikan pemerintah daerah untuk kepentingan uum dan mafaat umum serta dapat di nikmati oleh orang pribadi atau badan 
2. Jasa usaha, yaitu berupa pelayanan yang disediakan oleh pemerintah daerah dengan menganut sistem komersil.

3. Perizinan tertentu, yaitu kegiatan tertentu pemerintah daerah dalam rangka pemberian izin kepada orang pribadi atau badan yang dimaksud untuk pembinaan, pengaturan, pengadilan, dan pengawasan atas kegiatan pemanfaatan ruang, penggunaan sumberdaya alam, barang, prasarana, sarana atau fasilitas tertentu guna melindungi kepentingan umum dan menjaga kelestarian lingkungan.

\section{Wajib Retribusi}

Wajib retribusi daerah adalah orang pribadi atau badan yang menurut peraturan perundang-undangan retribusi diwajibkan untuk melakukan pembayaran retribusi, termasuk pungutan atau pemotongan retribusi daerah, berdasarkan Peraturan Pemerintah Nomor 66 tahun 2001 wajib retribusi dapat merupakan subjek retribusi tersebut.

\section{METODOLOGI PENELITIAN}

Metode yang digunakan dalam penelitian ini adalah deskriptif kuantitatif dengan menggunakan data-data berbentuk angka baik secara langsung digali dari hasil penelitian maupun pengolahan data kualitatif menjadi data kuantitatif.

\section{Teknik Pengumpulan Data}

Teknik pengumpulan data yang digunakan adalah dengan field research dan library research, yaitu menggunakan data primer dan sekunder. Data primer dikumpulkan di tempat usaha yang menjadi objek penelitian. Pengumpulan data dilakukan dengan melakukan wawancara dengan pihak Dinas Tata Kota dan Lingkungan Hidup Kota Metro dan Dinas Pendapatan Daerah Kota Metro. Dan menggunakan data sekunder, yaitu anggaran realisasi pendapatan dan belanja dinas tata kota dan lingkungan hidup Kota Metro dan realisasi retribusi/PAD Kota Metro pada Dinas Pendapatan Kota Metro.

\section{Alat Analisis Data}

Studi kuantitatif, studi komparatif, serta dapat juga menjadi sebuah studi korelasional satu unsur bersama unsur lainnya. Biasanya kegiatan penelitian ini meliputi pengumpulan data, menganalisis data, meginterprestasi data, dan diakhiri dengan sebuah kesimpulan yang mengacu pada penganalisisan data tersebut.

1. Retribusi pelayanan persampahan/kebersihan

Untuk mengukur besarnya kontribusi retribusi ini selain menggunakan data beberapa realisasi retribusi pelayanan persampahan/kebersihan terdapat pula biaya oprasional sebagai pengurang realisasi retribusi pelayanan persampahan/kebersihan, yang terdiri dari: biaya pemeliharaan kendaraan, biaya BBM, biaya cetak kartu retribusi, biaya alat kebersihan, biaya honor pekerja kebersihan. 
Yang digambarkan dengan rumus:

\begin{tabular}{|lll|}
\hline $\begin{array}{l}\text { Kontribusi retribusi } \\
\text { pelayanan } \\
\text { persampahan/kebersihan } \\
\text { terhadap PAD tahun- } n\end{array}$ & $\begin{array}{l}\text { Kontribusi retribusi } \\
\text { pelayanan } \\
\text { persampahan/kebersihan } \\
\text { tahun- } n\end{array}$ & $\begin{array}{l}\text { Biaya-biaya } \\
\text { oprasional } \\
\text { tahun- } n\end{array}$ \\
\hline
\end{tabular}

Sumber: Dasir Munir (2004:49)

Sedangkan untuk mengetahui persentase kontribusi ini terhadap PAD Kota Metro digambarkan dengan rumus:

$\%$ kontribusi retribusi pelayanan persampahan/kebersihan terhadap PAD tahun- $n$

$$
=\begin{aligned}
& \text { Kontribusi retribusi pelayanan } \\
& \text { persampahan/kebersihan tahun- X 100\% } \\
& n
\end{aligned}
$$

Realisasi PAD tahun- $n$

Sumber: Dasir Munir (2004:49)

2. Kontribusi reribusi jasa usaha penyedotan kakus

Untuk mengukur besarmya kontribusi retribusi ini selain menggunakan data berupa realisasi retribusi jasa usaha penyedotan kaskus terdapat pula biaya-biaya oprasional sebagai pengurang realisasi retribusi jasa usaha penyedotan kaskus, yang terdiri dari: biaya pemeliharaan kendaraan, biaya BBM, biaya honor pegawai.

Digambarkan dengan rumus:

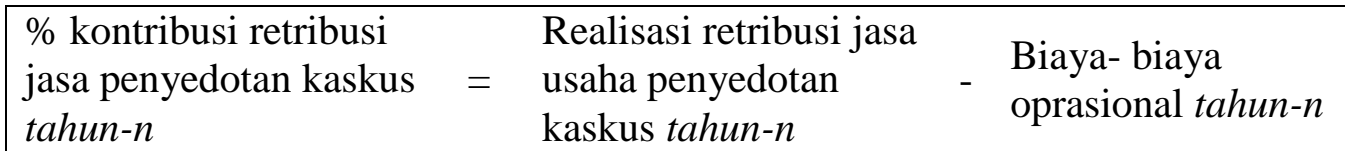

Sumber: Dasir Munir (2004:49)

Sedangkan untuk mengetahui persentase kontribusi ini terdapat PAD Kota Metro digambarkan dengan rumus:

$\%$ kontribusi

$\begin{aligned} & \text { retribusi jasa } \\ & \text { penyedotan kakus }\end{aligned} \quad=\begin{aligned} & \text { Kontribusi retribusi jasa usaha } \\ & \text { penyedotan kaskus tahun- } n\end{aligned} \quad$ X $\quad 100 \%$

tahun-n

Realisasi PAD tahun-n

Sumber: Dasir Munir (2004:49)

3. Kontribusi retribusi izin mendirikan bangunan (IMB) 
Untuk mengukur besarya kontribusi retribusi ini selain menggunakan data berupa realisasi retribusi izin mendirikan bangunan (IMB) terdapat pula biayabiaya oprasional sebagai pengurangan realisasi retribusi izin mendirikan bangunan (IMB), yang terdiri dari biaya cetak kartu digambarkan dengan rumus:

\begin{tabular}{|lll}
\hline$\%$ kontribusi retribusi & & Realisasi retribusi \\
izin mendirikan & izin mendirikan \\
bangunan tahun- $n$ & & $\begin{array}{l}\text { bangunan (IMB) } \\
\text { tahun- } n\end{array}$
\end{tabular}$\quad-\begin{aligned} & \text { Biaya- biaya } \\
& \text { oprasional tahun- } n\end{aligned}$

Sumber: Dasir Munir (2004:49)

Sedangkan untuk mengetahui persentase kontribusi ini terdapat PAD Kota Metro digambarkan dengan rumus:

$\begin{array}{ll}\begin{array}{l}\% \text { kontribusi retribusi } \\ \text { izin mendirikan } \\ \text { bangunan (IMB) } \\ \text { tahun- } n\end{array} & \begin{array}{l}\text { Kontribusi retribusi izin } \\ \text { mendirikan bangunan (IMB) } \\ \text { tahun } n\end{array}\end{array} \quad$ X $100 \%$

Realisasi PAD tahun- $n$

Sumber: Dasir Munir (2004:49)

4. Kontribusi retribusi izin peruntukan penggunaan tanah (IPPT)

Untuk mengukur besarnya kontribusi retribusi ini selain menggunakan data berupa realisasi retribusi izin peruntukan penggunaan tanah (IPPT) terdapat pula biaya-biaya oprasional sebagai peruntukan realisasi retribusi izin peruntukan penggunaan tanah (IPPT), yang terdiri dari: Biaya cetak kartu yang digambarkan dengan rumus:

\begin{tabular}{|lll|}
\hline \% kontribusi retribusi & Realisasi retribusi izin & Biaya - biaya \\
izin peruntukan & peruntukan penggunaan \\
penggunaan tanah & tanah (IPPT) tahun- $n$ & $-\quad$ oprasional tahun- \\
(IPPT) tahun- $n$ & & $n$ \\
\hline
\end{tabular}

Sumber: Dasir Munir (2004:49)

Sedangkan untuk mengetahui persentase kontribusi ini terhadap PAD Kota Metro digambarkan dengan rumus:

$\%$ kontribusi retribusi

izin peruntukan

penggunaan tanah

(IPPT) tahun- $n$

\author{
Kontribusi retribusi izin \\ $=$ peruntukan penggunaan tanah $\mathrm{X} 100 \%$ \\ (IPPT) tahun-n
}

Realisasi PAD tahun- $n$

Sumber: Dasir Munir (2004:49) 


\section{HASIL DAN PEMBAHASAN}

Hingga tahun 2014 Kota Metro mengelola 3 jenis retribusi daerah.

\section{Retribusi Jasa Umum}

- Retribusi Jasa Pelayanan Persampahan/Kebersihan yaitu: Pembayaran atas jasa pelayanan persampahan/kebersihan yang khusus disediakan dan atau diberikan oleh Pemerintah Daerah untuk kepentingan orang pribadi atau badan.

- Retribusi Pelayanan Parkir Ditepi Jalan Umum yaitu: Penyediaan pelayanan parkir di tepi jalan umum yang ditentukan oleh pemerintah daerah sesuai dengan ketentuan Peraturan Perundang-Undangan (Pasal 115 UndangUndang Nomor 28 Tahun 2009).

- Retribusi Pelayanan Pasar yaitu: penyediaan fasilitas pasar tradisional/sederhana berupa pelataran, los, kios yang dikelola pemerintah daerah, dan khusus disediakan untuk pedagang (Pasal 116 Undang-Undang Nomor 28 Tahun 2009).

2. Retribusi Jasa Usaha

- Retribusi Pasar Grosir/Pertokoan yaitu: penyediaan fasilitas pasar grosir berbagai jenis barang, dan fasilitas pasar/pertokoan yang dikontrakkan, yang disediakan/diselenggarakan oleh Pemerintah Daerah (Pasal 129 UndangUndang Nomor 28 Tahun 2009).

- Retribusi Tempat Khusus Parkir yaitu: pelayanan tempat khusus parkir yang disediakan, dimiliki, dan/atau dikelola oleh Pemerintah Daerah (Pasal 132 Undang-Undang Nomor 28 Tahun 2009)

- Retribusi Penyedotan Kakus yaitu: pelayanan penyediaan dan/atau penyedotan kakusyang dilakukan oleh Pemerintah Daerah (Pasal 120 Undang-Undang Nomor 28 Tahun 2009).

3. Retribusi Perizinan Tertentu.

- Retribusi Izin Mendirikan Bangunan yaitu: pemberian izin untuk mendirikan suatu bangunan. Pemberian izin meliputi kegiatan peninjauan desain dan pemantauan pelaksanaan pembangunannya agar tetap sesuai dengan rencana teknis bangunan dan rencana tata ruang, dengan tetap memperhatikan koefisien dasar bangunan (KDB), koefisien luas bangunan (KLB), koefisien ketinggian bangunan (KKB), dan pengawasan penggunaan bangunan yang meliputi pemeriksaan dalam rangka memenuhi syarat keselamatan bagi yang menempati bangunan tersebut (Pasal 142 UndangUndang Nomor 28 Tahun 2009).

- Retribusi Izin Peruntukan Penggunaan Tanah yaitu: Ijin Perencanaan dan/atau rekomendasi perencanaan bagi penggunaan tanah yang didasarkan pada Rencana Detail Tata Ruang Kota (RDTRK) dan/atau Rencana Teknik Ruang Kota (RTRK) 


\section{Kontribusi Retribusi Pelayanan Persampahan/Kebersihan terhadap Retribusi Jasa Umum Kota Metro tahun 2010 - 2014}

Cara perhitungan kontribusi Retribusi Pelayanan Persampahan/kebersihan terhadap Retribusi Jasa Umum

$$
\begin{array}{ll}
\begin{array}{l}
\text { Pendapatan Retribusi Pelayanan } \\
\text { Persampahan/Kebersihan }
\end{array} & \text { X 100\% }=\% \\
\text { Tahunan } & \text { Hasil } \\
\begin{array}{l}
\text { Pendapatan Retribusi Jasa } \\
\text { Umum Tahunan }
\end{array} &
\end{array}
$$

Tabel. 1

Tahun Pendapatan Retribusi Pelayanan Persampahan/Kebersihan Tahunan

$\begin{array}{ll}2010 & 281.000 .000 \\ 2011 & 177.242 .000 \\ 2012 & 221.242 .400 \\ 2013 & 254.400 .000 \\ 2014 & 281.000 .000\end{array}$

$\begin{array}{rr}\begin{array}{c}\text { Pendapatan } \\ \text { Retribusi Jasa } \\ \text { Umum Tahunan }\end{array} & \% \text { Hasil } \\ 18.923 .995 .956 & 01,49 \% \\ 634.336 .000 & 27,94 \% \\ 995.702 .000 & 22,22 \% \\ 2.092 .223 .000 & 12,16 \% \\ 1.524 .989 .000 & 18,43 \%\end{array}$

Sumber: data diolah 2015

Dari data diatas dapat diketahui bahwa kontribusi terbesar dari penerimaan retribusi pelayanan persampahan/kebersihan terhadap retribusi jasa umum selama 5 tahun terjadi pada tahun 2011 yaitu sebesar 27,94\%, sedangkan kontribusi terendahnya terjadi pada tahun 2010 yaitu sebesar $01,49 \%$

\section{Kontribusi Retribusi Pelayanan Parkir Ditepi Jalan Umum terhadap} Retribusi Jasa Umum Kota Metro tahun 2010 - 2014

Cara perhitungan kontribusi Retribusi Pelayanan Parkir Ditepi Jalan Umum terhadap Retribusi Jasa Umum

$$
\begin{aligned}
& \text { Pendapatan Retribusi Pelayanan } \\
& \text { Parkir Ditepi Jalan Umum X100\% }=\text { Hasil \% } \\
& \text { Tahunan } \\
& \text { Pendapatan Retribusi Jasa Umum } \\
& \text { Tahunan }
\end{aligned}
$$


Tabel. 2

$\begin{array}{rrrr}\text { Tahun } & \begin{array}{c}\text { Pendapatan Retribusi Pelayanan } \\ \text { Parkir Di Tepi Jalan } \\ \text { UmumTahunan }\end{array} & \begin{array}{c}\text { Pendapatan } \\ \text { Retribusi Jasa } \\ \text { Umum Tahunan }\end{array} & \begin{array}{c}\% \\ \text { Hasil }\end{array} \\ 2010 & 46.000 .000 & 18.923 .995 .956 & 0,24 \% \\ 2011 & 46.000 .000 & 634.336 .000 & 7,25 \% \\ 2012 & 75.000 .000 & 995.702 .000 & 7,53 \% \\ 2013 & 85.000 .000 & 2.029 .223 .000 & 4,18 \% \\ 2014 & 90.000 .000 & 1.524 .989 .250 & 5,90 \%\end{array}$

Sumber: data diolah 2015

Dari tabel diatas dapat diketahui bahwa kontribusi terbesar dari penerimaan retribusi jasa parkir di tepi jalan terhadap retribusi jasa umum selama 5 (lima) tahun terjadi pada tahun 2012, yaitu sebesar 7,53\% dan kontribusi terendah terjadi pada tahun 2010, yaitu sebesar $0,24 \%$.

Kontribusi Retribusi Retribusi Pelayanan Pasar terhadap Retribusi Jasa Umum Kota Metro tahun 2010 - 2014

Cara perhitungan kontribusi Retribusi Pelayanan Pasar terhadap Retribusi Jasa Umum

$$
\begin{aligned}
& \text { Pendapatan Retribusi Pelayanan } \\
& \text { Pasar Tahunan } \\
& \text { Pendapatan Retribusi Jasa Umum } \\
& \text { Tahunan }
\end{aligned} \quad \mathrm{X} 100 \%=\text { Hasil \% }
$$

Tabel.3

\begin{tabular}{rrrr} 
Tahun & $\begin{array}{c}\text { Pendapatan Retribusi } \\
\text { Pelayanan Pasar } \\
\text { Tahunan }\end{array}$ & \multicolumn{2}{c}{$\begin{array}{c}\text { Pendapatan Retribusi } \\
\text { Jasa Umum Tahunan }\end{array}$} \\
2010 & 112.000 .000 & 18.923 .995 .956 & $0,59 \%$ \\
2011 & 117.594 .000 & 634.336 .000 & $18,53 \%$ \\
2012 & 392.360 .000 & 995.702 .000 & $39,40 \%$ \\
2013 & 400.000 .000 & 2.029 .223 .000 & $19,71 \%$ \\
2014 & 800.000 .000 & 1.524 .989 .250 & $52,46 \%$
\end{tabular}

Sumber: data diolah 2015 
Dari tabel diatas dapat diketahui bahwa kontribusi terbesar dari penerimaan retribusi pelayanan pasar terhadap retribusi jasa umum selama 5 (lima) tahun terjadi pada tahun 2014, yaitu sebesar 52,46\% dan kontribusi terendah terjadi pada tahun 2010, yaitu sebesar 0,59\%.

Kontribusi Retribusi Pasar Grosir/Pertokoan terhadap Retribusi Jasa Usaha Kota Metro tahun 2010 - 2014

Cara perhitungan kontribusi Retribusi Pasar Grosir/Pertokoan terhadap Retribusi Jasa Usaha

$$
=\begin{aligned}
& \text { Pendapatan Retribusi Pasar } \\
& \text { Grosir/Pertokoan Tahunan } \\
& \text { Pendapatan Retribusi Jasa } \\
& \text { Usaha Tahunan }
\end{aligned}
$$

Tabel. 4

$\begin{array}{rrrr}\text { Tahun } & \begin{array}{c}\text { Pendapatan Retribusi } \\ \text { Pasar Grosir/Pertokoan } \\ \text { Tahunan }\end{array} & \begin{array}{c}\text { Pendapatan Retribusi } \\ \text { Jasa Usaha Tahunan }\end{array} & \text { \% Hasil } \\ 2010 & 699.900 .000 & 1.650 .656 .650 & 42,40 \% \\ 2011 & 99.900 .000 & 1.031 .282 .000 & 9,68 \% \\ 2012 & 530.000 .000 & 1.881 .349 .625 & 28,17 \% \\ 2013 & 600.000 .000 & 1.956 .445 .875 & 30,66 \% \\ 2014 & 600.000 .000 & 1.654 .778 .000 & 36,25 \%\end{array}$

Sumber: data diolah 2015

Dari tabel diatas dapat diketahui bahwa kontribusi terbesar dari penerimaan retribusi jasa usaha tahunan dari realisasi retribusi pasar grosir/pertokoan pelayanan selama 5 (lima) tahun terjadi pada tahun 2010, yaitu sebesar $42,40 \%$ dan kontribusi terendah terjadi pada tahun 2011, yaitu sebesar 9,68\%.

\section{Kontribusi Retribusi Tempat Khusus Parkir terhadap Retribusi Jasa Usaha} Kota Metro tahun 2010 - 2014

Cara perhitungan kontribusi Retribusi Tempat Khusus Parkir terhadap Retribusi Jasa Usaha

$$
\begin{array}{ll} 
& \text { Pendapatan Retribusi } \\
\text { Tempat Khusus Parkir } & \text { X100\% }=\text { Hasil } \\
\text { Tahunan } & \% \\
\text { Pendapatan Retribusi Jasa } & \\
\text { Usaha Tahunan } &
\end{array}
$$




\section{Tabel.5}

$\begin{array}{rrrr}\text { Tahun } & \begin{array}{c}\text { Pendapatan Retribusi } \\ \text { Tempat Khusus Parkir } \\ \text { Tahunan }\end{array} & \begin{array}{c}\text { Pendapatan Retribusi } \\ \text { Jasa Usaha Tahunan }\end{array} & \text { \% Hasil } \\ 2010 & 730.393 .250 & 1.650 .656 .650 & 44,24 \% \\ 2011 & 730.393 .250 & 1.031 .282 .000 & 70,82 \% \\ 2012 & 1.074 .393 .250 & 1.881 .349 .625 & 57,10 \% \\ 2013 & 1.074 .393 .250 & 1.956 .445 .875 & 54,91 \% \\ 2014 & 774.480 .000 & 1.654 .778 .000 & 46,80 \%\end{array}$

Sumber: data diolah 2015

Dari tabel diatas dapat diketahui bahwa kontribusi terbesar dari penerimaan retribusi jasa usaha tahunan dari realisasi retribusi pasar grosir/pertokoan pelayanan selama 5 (lima) tahun terjadi pada tahun 2011, yaitu sebesar 70,82\% dan kontribusi terendah terjadi pada tahun 2010, yaitu sebesar 44,24\%.

\section{Kontribusi Retribusi Penyedotan Kakus terhadap Retribusi Jasa Usaha Kota} Metro tahun 2010 - 2014

Cara perhitungan kontribusi Retribusi Penyedotan Kakus terhadap Retribusi Jasa Usaha

$$
=\begin{aligned}
& \text { Pendapatan Retribusi } \\
& \text { Penyedotan Kakus Tahunan } \\
& \begin{array}{l}
\text { Pendapatan Retribusi Jasa } \\
\text { Usaha Tahunan }
\end{array}
\end{aligned}
$$

Tabel.6

$\begin{array}{rrrr}\text { Tahun } & \begin{array}{c}\text { Pendapatan Retribusi } \\ \text { Penyedotan Kakus } \\ \text { Tahunan }\end{array} & \begin{array}{c}\text { Pendapatan Retribusi } \\ \text { Jasa Usaha Tahunan }\end{array} & \text { \% Hasil } \\ 2010 & 6.000 .000 & 1.650 .656 .650 & 0,36 \% \\ 2011 & 6.500 .000 & 1.031 .282 .000 & 0,63 \% \\ 2012 & 7.500 .000 & 1.881 .349 .625 & 0,39 \% \\ 2013 & 10.000 .000 & 1.956 .445 .875 & 0,51 \% \\ 2014 & 12.000 .000 & 1.654 .778 .000 & 0,72 \%\end{array}$

Sumber: data diolah 2015 
Dari tabel diatas dapat diketahui bahwa kontribusi terbesar dari penerimaan retribusi jasa usaha tahunan dari realisasi retribusi penyedotan kakus selama 5 (lima) tahun terjadi pada tahun 2014, yaitu sebesar 0,72\% dan kontribusi terendah terjadi pada tahun 2010, yaitu sebesar 0,36\%.

Kontribusi Retribusi Izin Mendirikan Bangunan (IMB) terhadap Retribusi Perizinan Tertentu Kota Metro tahun 2010 - 2014

Cara perhitungan kontribusi Retribusi Izin Mendirikan Bangunan terhadap Retribusi Jasa Perizinan Tertentu

$\begin{array}{lrl}\begin{array}{l}\text { Pendapatan } \\ \text { Mendirikan }\end{array} & \text { Retribusi Izin } \\ \text { Bangunan } & \\ \text { Tahunan } & \text { X 100\% }=\text { Hasil \% } \\ & \begin{array}{l}\text { Pendapatan } \\ \text { Perizinan Tertentu Tahunan }\end{array}\end{array}$

Tabel. 7

$\begin{array}{rrrr}\text { Tahun } & \begin{array}{c}\text { Pendapatan Retribusi } \\ \text { IMB Tahunan }\end{array} & \begin{array}{c}\text { Pendapatan Retribusi Jasa } \\ \text { Perizinan Tertentu } \\ \text { Tahunan }\end{array} & \text { \% Hasil } \\ 2010 & 302.241 .740 & 512.191 .740 & 59 \% \\ 2011 & 310.000 .000 & 442.500 .000 & 70,05 \% \\ 2012 & 355.000 .000 & 522.500 .000 & 64,11 \% \\ 2013 & 500.000 .000 & 810.000 .000 & 61,72 \% \\ 2014 & 1.104 .660 .000 & 1.512 .160 .000 & 73,05 \%\end{array}$

Sumber: data diolah 2015

Dari tabel diatas dapat diketahui bahwa kontribusi terbesar dari penerimaan retribusi IMB tahunan dari realisasi retribusi jasa perizinan tertentu tahunan selama 5 (lima) tahun terjadi pada tahun 2014, yaitu sebesar 73,05\% dan kontribusi terendah terjadi pada tahun 2010, yaitu sebesar 59\%.

Kontribusi Retribusi Izin Peruntukan Pengunaan Tanah terhadap Retribusi Perizinan Tertentu Kota Metro tahun 2010 - 2014

Cara perhitungan kontribusi Retribusi Izin Peruntukan Penggunaan Tanah terhadap Retribusi Jasa Perizinan Tertentu

$$
\begin{aligned}
& \text { Pendapatan Retribusi Izin Peruntukan } \\
& \begin{array}{l}
\text { Penggunaan Tanah Tahunan } \\
\text { Pendapatan Retribusi Jasa Perizinan }
\end{array} \\
& \text { Tertentu Tahunan }
\end{aligned}
$$


Tabel. 8

$\begin{array}{rrrr}\text { Tahun } & \begin{array}{c}\text { Pendapatan Retribusi } \\ \text { IPPT Tahunan }\end{array} & \begin{array}{c}\text { Pendapatan Retribusi Jasa } \\ \text { Perizinan Tertentu } \\ \text { Tahunan }\end{array} & \text { \% Hasil } \\ 2010 & 40.400 .000 & 512.191 .740 & 7,88 \% \\ 2011 & 48.350 .000 & 442.500 .000 & 10,92 \% \\ 2012 & 60.737 .000 & 522.500 .000 & 11,62 \% \\ 2013 & 68.475 .000 & 810.000 .000 & 8,45 \% \\ 2014 & 80.950 .000 & 1.512 .160 .000 & 5,35 \%\end{array}$

Sumber: data diolah 2015

Dari tabel diatas dapat diketahui bahwa kontribusi terbesar dari penerimaan retribusi IPPT tahunan dari realisasi retribusi jasa perizinan tertentu tahunan selama 5 (lima) tahun terjadi pada tahun 2012, yaitu sebesar $11,62 \%$ dan kontribusi terendah terjadi pada tahun 2014, yaitu sebesar 5,35\%.

\section{Rata - rata kotribusi retribusi daerah terhadap PAD Kota Metro}

Rata - rata kontribusi retribusi daerah terhadap Pendapatan Asli Daerah kota Metro selama kurun waktu lima tahun dari tahun 2010 hingga tahun 2014:

Tabel. 9 Rata - rata Kontribusi Retribusi Daerah terhadap PAD Kota Metro

$\begin{array}{clc}\text { No. } & \text { Retribusi Daerah } & \text { Rata }- \text { rata } \\ 1 & \text { Hasil PAD lain - lain } & 67,22 \% \\ 2 & \text { Retribusi Jasa Umum } & 27,91 \% \\ 3 & \text { Retribusi Jasa Usaha } & 3,77 \% \\ 4 & \begin{array}{l}\text { Reribusi Perizinan } \\ \text { Tertentu }\end{array} & 2,10 \% \\ & \end{array}$

Sumber: data diolah 2015

Kontribusi tiap jenis retribusi daerah terhadap penerimaan PAD dalam kurun waktu tahun anggaran 2010 hingga 2014 sangat flukuatif. Kontribusi terdapat pada retribusi Jasa Umum yaitu dengan rata - rata kontribusi lima tahun sebesar 27\%, Retribusi Jasa Usaha 4\%, Retribusi Perizinan Tertentu 2\% Sedangkan 67\% adalah hasil dari PAD lainnya yang bersumber dari Pajak Hotel, Pajak Hiburan, Pajak Reklame, Pajak Penerangan Jalan (PLN dan KLP Siwo Mego), Pajak Penggalian Bahan Galian Golongan C dan Pajak Pengusahaan Sarang Walet dan Seriti. 


\section{KESIMPULAN}

Berdasarkan dari hasil penelitian dan pembahasan yang telah dilakukan dapat di ambil kesimpulan sebagai berikut:

Kontribusi terbesar selama lima tahun dari tahun 2010 hingga 2014 dari retribusi daerah PAD berasal dari retribusi jasa umum yaitu dengan rata - rata sebesar Retribusi Jasa Umum 27, 91\%, Retribusi Jasa Usaha 3, 77\%, Retribusi Perizinan Tertentu 2, 10\%, Retribusi Jasa Umum di Kota Metro merupakan retribusi yang disediakan atau diberikan oleh pemerintah daerah untuk tujıan kepentingan dan kemanfaatan umum yang dapat dinikmati orang pribadi a au badan. Sedangkan dua retribusi lainnya yaitu retribusi jasa usaha dan retribusi perizinan tertentu tingkat kontribusinya belum sebesar retribusi jasa umum.

\section{DAFTAR PUSTAKA}

Akbar, Taufik, 2012. Pengaruh Pendapatan Asli Daerah (PAD) dan Dana Alokasi Umum (DAU) Terhadap Belanja Modal. Skripsi yang tidak diterbitkan, Bandung: Univeristas Pasundan Bandung

Halim, Abdul. 2004. Akuntansi Sektor Publik Keuangan Daerah. Jakarta: penerbit Salemba Empat

Anita, 2012."Kontribusi retribusi daerah dalam menunjang PAD, studi kasus:Dinas Pendapatan Kota Bandar Lampung". Skripsi Fisip UNY, Yogyakarta.

Mardiasmo, 2003. Otonomi Daerah dalam dan Manajemen Keuangan Daerah. Yogyakarta, Andi Offiset.

Undang - Undang Otonomi 1999. Sinar Grafika, Jakarta.

Sulistiyorini, Nety Retraningdiyah. 2006, “Analisis Penerimaan Pajak Daerah dan Retribusi Daerah untuk Meningkatkan Kemampuan Daerah Pemerintahan Kabupaten Kediri Tahun Anggaran 2000-2003”, Artikel

http://padjakdaerah.blogspot.com/2012/08/pengertian-pajak-daerah-danretribusi.html

http://kpmptsp.metrokota.go.id/index.php?option=comcontent $\& v i e w=\operatorname{article} \& i d=$ 180:artikel-ketentuan-im 